University of Northern Colorado

Scholarship \& Creative Works @ Digital UNC

$4-12-2012$

Between a Rock and a Hard Place: Managing Government Document Collections in a Digital World

Jennifer Nutefall

Michael H. Boock

Steven L. Sowell

Lawrence A. Landis

Follow this and additional works at: https://digscholarship.unco.edu/libfacpub

Part of the Library and Information Science Commons 
This article was downloaded by: [Oregon State University], [Michael Boock] On: 17 April 2012, At: 08:20

Publisher: Routledge

Informa Ltd Registered in England and Wales Registered Number: 1072954 Registered office: Mortimer House, 37-41 Mortimer Street, London W1T 3J H, UK

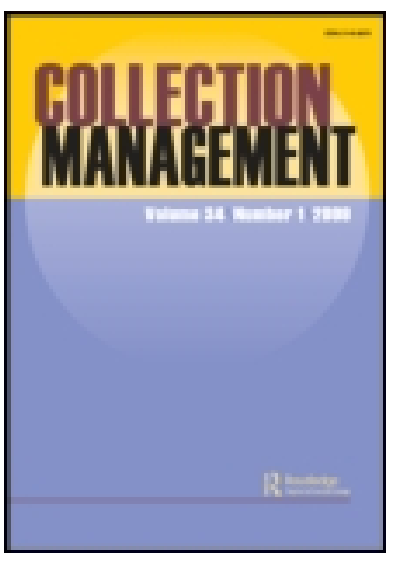

\section{Collection Management}

Publication details, including instructions for authors and subscription information:

http:// www.tandfonline.com/loi/ wcol20

\section{Between a Rock and a Hard Place: Managing Government Document Collections in a Digital World}

Steven L. Sowell ${ }^{a}$, Michael H. Boock ${ }^{a}$, Lawrence A. Landis ${ }^{a} \&$ Jennifer E. Nutefall ${ }^{\text {a }}$

${ }^{a}$ Oregon State University Libraries, Corvallis, Oregon

Available online: 12 Apr 2012

To cite this article: Steven L. Sowell, Michael H. Boock, Lawrence A. Landis \& J ennifer E. Nutefall (2012): Between a Rock and a Hard Place: Managing Government Document Collections in a Digital World, Collection Management, 37:2, 98-109

To link to this article: http:// dx. doi.org/ 10.1080/01462679.2012.656554

\section{PLEASE SCROLL DOWN FOR ARTICLE}

Full terms and conditions of use: http://www.tandfonline.com/page/terms-and-conditions

This article may be used for research, teaching, and private study purposes. Any substantial or systematic reproduction, redistribution, reselling, loan, sub-licensing, systematic supply, or distribution in any form to anyone is expressly forbidden.

The publisher does not give any warranty express or implied or make any representation that the contents will be complete or accurate or up to date. The accuracy of any instructions, formulae, and drug doses should be independently verified with primary sources. The publisher shall not be liable for any loss, actions, claims, proceedings, demand, or costs or damages whatsoever or howsoever caused arising directly or indirectly in connection with or arising out of the use of this material. 


\title{
Between a Rock and a Hard Place: Managing Government Document Collections in a Digital World
}

\author{
STEVEN L. SOWELL, MICHAEL H. BOOCK, LAWRENCE A. LANDIS, \\ and JENNIFER E. NUTEFALL \\ Oregon State University Libraries, Corvallis, Oregon
}

\begin{abstract}
An Oregon State University Libraries (OSUL) study group's review of its current policies, practices, and costs provides an illustrative case study of the challenges in managing government documents during this period of transition from print to digital. In its exploration of more aggressive approaches to greatly increasing access to electronic collections and reducing the size of the print footprint, OSUL learned that the current requirements of the Federal Depository Library Program (FDLP) hamper such efforts. This case study provides background on prior internal studies, OSUL's participation in a shared bousing agreement, statistics on size and current usage of its government documents, and the costs to receive, process, and provide access to its document collection. It concludes with the recommendations for OSUL to be as proactive as it can be under the current FDLP rules and regulations while bringing projected costs to manage government documents more in line with higher priorities.
\end{abstract}

KEYWORDS government documents, cost analysis, Federal Depository Library Program (FDLP), return on investment, collection management

“... wherever the people are well informed they can be trusted with their own government ..."

—Thomas Jefferson

Address correspondence to Steven L. Sowell, Head of Collections and Resource Sharing, Oregon State University, 121 The Valley Library, Corvallis, OR 97331. E-mail: steven.sowell@ oregonstate.edu 


\section{INTRODUCTION}

Since its establishment in 1813, the Federal Depository Library Program (FDLP) has focused on the mission to provide the public with access to our government's information and to meet our government's obligation to disseminate, provide access to, and preserve its information. A widely held value since the time of Thomas Jefferson and James Madison is that an informed citizenry is essential for a truly functioning democracy. As the information world has grown increasingly digital, many academic libraries throughout the United States have examined their continuing participation in the FDLP. In their desire to respond to needs of their constituents for electronic access to information and complete the transition from print to digital collections, academic libraries have found that they are hampered in achieving these goals by the legal requirements and program regulations that mandate that they retain large quantities of tangible documents in perpetuity. Some libraries have chosen to withdraw from the FDLP (see for example McKenzie, Dugan, and Djorup 2000; Lev, Gilbert, Olson, and Gonce 2002), while others have greatly reduced their commitments in an effort to control the physical growth of document collections and the accompanying costs to process, provide access, and house these collections.

This article provides a case study of how one academic library reviewed its participation in FDLP and resolved to balance the desire to assist in creating an informed citizenry with the need to utilize limited resources to meet a broad range of priorities. With nearly 1,250 depository libraries currently in the program, how the Oregon State University Libraries (OSUL) approached the problem, what data it collected and analyzed, and what choices it made should be instructive for any library, particularly other academic libraries in analogous settings with similar aspirations and limitations.

\section{BACKGROUND}

OSUL has been a selective depository collection since 1907. In 2007, a shared housing agreement was signed among OSUL, Oregon State Library, Portland State University Library, and the University of Oregon Libraries so that these four institutions would serve together as the regional library for the state of Oregon. OSUL agreed to select and retain in perpetuity one tangible copy of every publication from a group of agencies relevant to campus interests (see Appendix A for a list of agencies). As part of the shared housing agreement, if any of the four institutions decided to remove itself from the agreement, a year's notice would be required. The shared housing agreement has not yet been fully implemented by OSUL because of other pressing issues or by any of the other libraries participating in it. This inaction was part of the impetus for the current review by the study team. 
In October 2011, four members of the OSUL management team were charged to investigate the current status of the FDLP and how its policies and procedures and our agreements impact the libraries. Discussions on what to do about government documents had occurred before. In October 2010, library administrators asked two librarians, one of whom was the government documents specialist, to assess the status of the current depository library program and outline the advantages and disadvantages of retaining status as a federal depository library. Their report provided a brief history of the FDLP; provided statistics on OSUL holdings and use of federal government documents; outlined obligations as a selective depository and as a participant in a shared agreement for the regional depository; analyzed two case studies of withdrawal from the FDLP; discussed the benefits of participating in the FDLP; listed the advantages and disadvantages of withdrawing from the program; and finally, recommended that "a decision to withdraw from the FDLP at this time would be, at the very least, premature" (King and Chau 2011).

As a selective depository and part of the shared housing agreement for the regional depository collection, OSUL's potential actions are limited by the legal requirements and program regulations of the FDLP (FDLP 2011a). If OSUL wants to remain in the program and share in the responsibility to provide the citizens of Oregon access to government information, it gives up control over what publication formats it acquires (print or microform only), how its acquisitions are processed and accessed, and how long it has to retain items (permanently). With persistent funding issues, finite shelving space, a growing reliance on digital access and delivery of information, and increasingly effective collaborative preservation initiatives, this lack of control over its resources is especially onerous.

OSUL's current selections result in receiving $80.04 \%$ of the total items offered. If the shared housing agreement was fully implemented to receive only those agencies OSUL agreed to select (approximately 25\%) and in combination with the $8 \%$ to $10 \%$ in the basic collection (FDLP 2011b), the selection total would be approximately 35\%. OSUL can follow the mandated withdrawal procedures and withdraw tangible items that others have agreed to retain. Additional issues for OSUL include the amount of staff time (approximately 1.2 full-time equivalent) devoted to checking in, cataloging, and processing government documents and the fact that a large number of documents distributed before 1976 are not cataloged and consequently do not appear in online catalog search results.

OSUL is a member of the Orbis Cascade Alliance, the Greater Western Library Alliance (GWLA), and several other academic library partnerships. Since membership has enabled the library to collaboratively pursue a growing number of digital solutions to other access and preservation challenges, the OSUL has hoped that joint action on government document access and preservation would be an option. The GWLA Government Documents Task 
Force investigated and developed a plan similar to the one developed in 2009 by the Association of Southeastern Libraries (ASERL). The task force members identified the challenges in developing a cooperative approach to the management of federal government documents. However, recent actions of the superintendent of documents call into question the ability to adopt and implement an ASERL-like plan.

In response, the Association of Research Libraries (ARL) issued a statement in October 2011 that "calls upon the Government Printing Office (GPO) to reverse its recent, troubling decisions concerning the Federal Depository Library Program (FDLP).... Recently, changes in policy and practice by GPO and its failure to embrace needed changes to the Program present serious challenges to the Program's sustainability and viability. These changes will seriously impact the ability of the public to effectively access government information both now and in the future (Association of Research Libraries 2011)." GWLA, ASERL, and the Committee on Institutional Cooperation also responded strongly.

Librarians across the country have expressed concern about the ability of academic libraries to continue the transformation to mostly digital collections because of the current policies of FDLP. The final paragraph of the ARL statement encapsulates why many libraries feel like they are between a rock and hard place. "The public's growing preference for digital delivery of information, coupled with serious costs and constraints of library space, provide compelling motivation for the FDLP to proactively address discovery and delivery of the full corpus of depository publications in digital form and to positively engage and facilitate partnership with the FDLP community in this effort." An extensive list of references related to this issue and its debate is maintained by the American Library Association (ALA) on its Web site (American Library Association 2011).

\begin{abstract}
ANALYSIS
Building on the previous study of OSUL's participation in the FDLP, the study team undertook an analysis of the scope of the government documents collection, its growth, its use, and the financial impacts on the library. OSUL's federal depository materials include monographs, serials, maps, reports, videos, posters, and flyers in paper, microforms, CDs, DVDs, and electronic resources via the Internet. From 2010 to 2011, the size of OSUL's federal documents had grown by nearly 44,600 items, from an estimated 473,080 to 517,677 (8.6\%). The formats and quantities are listed in Table 1. The agencies that are most highly represented are listed in Table 2.

The acquisitions cover the specific agencies that OSUL agreed to accept per the statewide agreement. Other agencies, however, seem to be overrepresented-Energy, Environment, Health \& Human Services, Labor,
\end{abstract}


TABLE 1 OSUL Government Document Holdings

\begin{tabular}{lr}
\hline Format (cataloged) & Quantity \\
\hline Paper & 349,701 \\
Microform & 63,750 \\
Electronic & 98,147 \\
Maps* & 4,658 \\
CDs & 1,383 \\
Posters & 38 \\
\hline *A large percentage of government document maps are not individually cat- \\
aloged.
\end{tabular}

State, and Transportation-even taking into account the FDLP basic collection requirements. The agencies represented in these yearly acquisitions tend to mirror the agencies that are most highly represented in the overall collection. The conclusion is that OSUL is acquiring a larger number of federal publications than agreed to in the shared housing agreement.

Are the government documents used? A review of the catalog provides circulation data for the past two years and reveals that a total of 1,106 government document items circulated in 2010 and 1,000 items in 2011. While in-house usage statistics are not available, the data available represents less than $1 \%$ of the total number of items circulated by OSUL during these time periods. Although the focus of the study team was on the tangible collections, statistics are also available on the use of government documents in digital form from 2009 through 2011. "Click-through" statistics show that electronic government documents were accessed 958 times in this time period. In addition, access to government documents directly through the online catalog totaled 3,151 for 2009-2011. (Three months of Persistent Uniform Resource Locator (PURL) data are missing for 2009).

Of the 2,106 circulation transactions for 2010 and 2011, the documents circulating the most, by agency, are listed in Table 3. Agencies that are well represented in the collection but have had little circulation activity over the

TABLE 2 Most Highly Represented Agencies in OSUL Documents Collection

\begin{tabular}{lc}
\hline Agency & Number of Items \\
\hline Congress/Independent Commissions & 120,422 \\
Interior Department & 68,671 \\
NASA & 61,838 \\
Government Accountability Office & 46,132 \\
USDA & 42,536 \\
HHS Department & 28,180 \\
Commerce Department & 27,478 \\
EPA & 21,278 \\
Transportation Department & 17,052 \\
\hline
\end{tabular}


TABLE 3 Circulation of Documents by Agency

\begin{tabular}{lcc}
\hline Agency & $\begin{array}{c}\text { Total Circulation } \\
2010 \text { and 2011 }\end{array}$ & $\begin{array}{c}\text { \% of Total Government } \\
\text { Documents Circulation }\end{array}$ \\
\hline Agriculture & 807 & $39 \%$ \\
Interior & 353 & $17 \%$ \\
Congress/Ind. Commissions & 249 & $12 \%$ \\
Defense & 120 & $6 \%$ \\
HHS & 102 & $5 \%$ \\
State & 78 & $4 \%$ \\
Smithsonian & 78 & $4 \%$ \\
Commerce & 62 & $3 \%$ \\
\hline
\end{tabular}

past two years are listed in Table 4. This could be an indicator that the government documents for those agencies that are well represented in our collection but that are neither part of the statewide agreement responsibilities nor part of the FDLP basic collection (all of the above except NASA), could be considered candidates for deaccessioning.

Two other statistics are worth noting. First, since July 1, 2010, two patrons have used the hard copy of the Serial Set. Second, during November and December 2011, 18 U.S. Geological Survey topographic maps, 1 U.S. Geological Survey CD, 97 microfiche documents, and 6 reels of National Archives-produced microfilm were refiled. This is significantly low usage for these formats.

See Appendix B for the amount of floor space devoted to the government documents collection and Appendix $\mathrm{C}$ for a map of locations on the third floor of the Valley Library.

\section{FINANCIAL IMPACTS}

When considering the total costs related to government documents collections in an academic library, it is necessary to consider staffing and vendor

TABLE 4 Least Circulated Documents by Agency

\begin{tabular}{lcc}
\hline Agency & $\begin{array}{c}\text { Total Number } \\
\text { of Documents }\end{array}$ & $\begin{array}{c}\text { Total Circulation } \\
\text { 2010 and 2011 }\end{array}$ \\
\hline Energy & 8,290 & 10 \\
Environment & 12,509 & 17 \\
Government Accountability Office & 23,301 & 4 \\
Justice & 4,479 & 20 \\
Labor & 4,329 & 23 \\
NASA & 42,475 & 18 \\
Treasury & 3,523 & 0 \\
Transportation & 11,153 & 12 \\
\hline
\end{tabular}


costs for cataloging, processing, and shelving documents and the cost to keep the materials on the shelves. Return on investment for government documents is calculated using costs against circulation of government documents. The financial impact of withdrawing items from the collection is also considered.

OSUL has one subject liaison with a total of $20 \%$ of her job devoted to collection development for several disciplines in addition to government documents selection. Selection of government documents represents a small percentage of this work, which is estimated to be $5 \%$.

A Library Technician 3 is responsible for a variety of tasks related to cataloging government documents and coordinating the processing of them. One hundred percent of this person's time is devoted to this work. A second Library Technician 3 loads catalog records from a cataloging vendor and performs some database maintenance on documents records. This constitutes approximately 10\% of her time. A Library Technician 2 spends approximately $10 \%$ of her time checking in documents serials.

One student worker devotes approximately five hours per week to unpacking, verifying shipping lists, and processing new documents receipts, and a Library Technician 1 devotes 2 to 3 hours per week shelving and reshelving government documents. See Table 5 for a full breakdown of staffing and shelving costs.

The federal print documents collection shelved in SuDocs classification at Valley Library occupies approximately 2,592 square feet of the floor shelf space. Approximately half of the government documents in Valley Library are shelved in Library of Congress classification on other floors of the library, so it is conservatively estimated that a total of 5,000 square feet is devoted to print documents. Another 544 square feet is devoted to federal document maps, the Serial Set, microforms, compact disks, and other formats of material. This

TABLE 5 Current Staffing and Shelving Costs

\begin{tabular}{lccr}
\hline & $\begin{array}{c}\text { Percentage of } \\
\text { Time Spent } \\
\text { on Documents }\end{array}$ & $\begin{array}{c}\text { Annual } \\
\text { Salary and } \\
\text { Benefits }\end{array}$ & $\begin{array}{c}\text { Annual } \\
\text { Cost }\end{array}$ \\
\hline Associate Professor & $5 \%$ & $\$ 81,649$ & $\$ 4,082$ \\
LT3-1 (cataloging) & $100 \%$ & $\$ 68,403$ & $\$ 68,403$ \\
LT3-2 (cataloging) & $10 \%$ & $\$ 65,983$ & $\$ 6,598$ \\
LT2 (check in) & $10 \%$ & $\$ 59,392$ & $\$ 5,939$ \\
Student (processing) & 5 hours/week & $\$ 9.06 / \mathrm{hr}$ & $\$ 2,363$ \\
LT1 (shelving) & $10 \%$ & $\$ 53,839$ & $\$ 5,383$ \\
Cataloging vendor & Number of Items & $\$ 5,690$ \\
& 349,701 & $\$ 4.26$ & $\$ 1,489,726$ \\
Costs to shelve & & & $\$ 1,588,184$ \\
Total cost & & & Cost per Item \\
\hline
\end{tabular}


does not include small collections of federal documents housed at OSUL's two branch libraries.

One way of calculating the cost of shelving-and this method applies to all books, not just government documents-is to use an annual cost estimate for keeping a book on a shelf multiplied by the total number of print government document volumes in the library collections. Courant and Nielsen (2010) calculate the annual cost of storing a print book (including serial volumes) in an open stack to be $\$ 4.26$ based on construction costs, facility maintenance, cleaning, electricity, and staffing responsible for storage and circulation. (For consideration, federal documents may generally be smaller in mass than volumes in the general collection.) By multiplying the total number of print government document volumes in the library collections $(349,701)$ with this figure $(\$ 4.26)$ we get an annual cost of shelving and managing government documents of $\$ 1,489,726$. Paper volume additions to the collections totaled 2,161 in fiscal year 2011. If the print collection continues to grow at this rate, the cost to shelve increases $\$ 9,205$ annually, for a total cost of $\$ 1,498,931$.

If the libraries were to withdraw all documents except those OSUL agreed to or is otherwise required to retain, annual costs to shelve paper are reduced from $\$ 1,489,726$ to approximately $\$ 521,402$. This figure is calculated by correlating the percentage of items that are currently selected with the percentage of items from particular agencies that are currently in our collections. In other words, 35\% (the percentage of documents that OSUL is required to retain) of all the libraries paper documents is 122,395 (A). The difference between this number and the total number of documents in the collection $(349,701)$ is 227,306 , the number of documents that can be considered for deselection. To calculate the cost of retaining the documents that the libraries have agreed to retain, multiply A by the estimated annual cost to store a book (4.26) to arrive at $\$ 521,402$.

The costs to reduce the government documents collection are not insignificant and should be factored into the decision process. In an article on deselection, Rick Lugg estimated that it costs $\$ 3.20$ to deselect a volume from a library (Lugg 2011). Using this estimate, it would cost the library $\$ 726,400$ to deselect and withdraw the approximately 227,000 items that are not in agencies OSUL has agreed to collect under the shared housing agreement.

Since government documents received from GPO are preprocessed and shelf-ready, since OSUL pays a cataloging vendor for the cataloging of these documents, and since the return on investment for government documents is so low, the study group proposes that documents received be accessioned into the collection as is. This means that staff would no longer provide individual item check-in of serial documents but instead maintain summary holdings statements. Student staff would continue to check shipping lists of new receipts to meet GPO requirements. Table 6 outlines the proposed staffing and shelving costs. These revised costs would result in expending $\$ 1,015,063$ less per year for shelving and managing the government 
TABLE 6 Proposed Staffing and Shelving Costs

\begin{tabular}{lccr}
\hline Position & $\begin{array}{c}\text { Percentage of } \\
\text { Time Spent } \\
\text { on Documents }\end{array}$ & $\begin{array}{c}\text { Annual } \\
\text { Salary and } \\
\text { Benefits }\end{array}$ & $\begin{array}{c}\text { Annual } \\
\text { Cost }\end{array}$ \\
\hline Associate Professor & $5 \%$ & $\$ 81,649$ & $\$ 4,082$ \\
LT3-1 (cataloging) & $50 \%$ & $\$ 68,403$ & $\$ 34,201$ \\
Student (processing) & 4 hours/week & $\$ 9.06 / \mathrm{hr}$ & $\$ 2,363$ \\
LT1 (shelving) & $10 \%$ & $\$ 53,839$ & $\$ 5,383$ \\
Cataloging vendor & Number of Items & Cost per Item & $\$ 5,690$ \\
\hline Costs to shelve & 227,306 & $\$ 4.26$ & $\$ 521,402$ \\
Total cost & & $\$ 573,121$ \\
\hline
\end{tabular}

documents collection after the weeding project has been completed and workflows revised. Rather then expending $\$ 1,489,726$ to shelve the collections, only $\$ 521,402$ would be expended.

In addition to fiscal costs, the space and time devoted to shelving and managing government documents also represents an opportunity cost. Other potential uses of floor space, such as the creation of a scholar's laboratory, have recently been discussed. Removing federal documents that we are no longer required to hold frees up valuable space. Reassigning a portion of the staff time currently devoted to documents processing and cataloging activities enables them to undertake other work of the libraries deemed more valuable and strategic.

\section{CONCLUSIONS}

The libraries at Oregon State University embrace the role of providing the citizens of the region and state access to government information. However, as important as this role is to an informed citizenry, it has to be balanced with its costs and the many other responsibilities it must fulfill in connecting faculty and students with the information they need for research, teaching, and learning. OSUL's efforts to find the right balance between its roles and their costs are continual. In 2007, OSUL entered into a shared housing agreement with the Oregon State Library, Portland State University, and the University of Oregon to jointly serve as the regional depository library for the state of Oregon. Based on the analysis and discussion above, the study group concluded that it is now time to fully implement the shared housing agreement. The specific actions recommended are the following:

- Per the shared housing agreement, immediately deselect documents from agencies for which the OSUL is not responsible (see Appendix A), reducing the current coverage of titles from approximately $80.04 \%$ to less than $35 \%$. 
- Receive all of the required titles in the basic collection as electronic only except for USA Counties and the Statistical Abstract of the United States because of copyright restrictions that prevent the inclusion of some tables in the electronic versions of those titles.

- Because of its important historical value, transfer management responsibility for the Serial Set to the Special Collections \& Archives Research Center.

- Discontinue check-in of government document serials as described above.

- In collaboration with the regional depository library, plan and conduct a weeding project during the summer of 2012 to remove tangible documents that we are not required to retain. This work should follow the legal requirements and regulations of the FDLP.

- Review annually the management of government documents following implementation of the above recommendations.

Following broad discussion with the library's management group, staff, and users, the next steps for the study group will be to develop specific plans and assignments to implement these recommendations. The management of government document collections in those libraries participating in the FDLP will remain a continual concern until Congress and the GPO develop more pragmatic legal requirements and program regulations for the FDLP. With a growing reliance on robust and trusted digital repositories, it is past time to acknowledge that far fewer tangible collections are needed to ensure that there is an informed citizenry.

\section{ACKNOWLEDGMENTS}

The study team thanks and acknowledges Valery King and May Chau for the thorough work that went into the earlier report that served as both a resource and starting point for this case study. The study team is also grateful to Valery for answering numerous questions and providing advice and recommendations during this investigation. In addition, the team wishes to thank Laurel Kristick for gathering many of the statistics used in this report. Finally, thanks to Janet Webster for her thorough editorial review and to Philip Vue for his assistance creating the map for Appendix C.

\section{REFERENCES}

American Library Association. 2011. Federal Depository Library Program. Available at: http://www.ala.org/ala/issuesadvocacy/advleg/federallegislation/govinfo/fdlp/ index.cfm (accessed December 30, 2011).

Association of Research Libraries. 2011. ARL statement on recent USGPO decisions concerning the FDLP. Available at: http://www.arl.org/bm $\sim \mathrm{doc} / \mathrm{fdlp}$ arlstatement_12oct11.pdf (accessed December 30, 2011). 
Courant, Paul N., and Matthew Nielsen. 2010. "On the cost of keeping a book." In The Idea of Order: Transforming Research Collections for 21st Century Scholarship, 81-105. Washington, DC: Council on Library and Information Resources.

FDLP. 2011a. Legal requirements \& program regulations of the Federal Depository Library Program. Available at: http://purl.fdlp.gov/GPO/gpo9182 (accessed December 30, 2011).

FDLP. 2011b. Basic collection. Available at: http://www.fdlp.gov/basicollection (accessed December 30, 2011).

King, Valery, and May Chau. 2011. Oregon State University Libraries and depository status: An investigation. Available at: http://ir.library.oregonstate.edu/xmlui/ handle/1957/21932 (accessed December 30, 2011).

Lev, Yvonne T., Mary Gilbert, Carl Olson, and Nancy Gonce. 2002. Making the decision to relinquish U.S. document depository status. portal: Libraries and the Academy 2: 413-422.

Lugg, Rick. 2011. The cost of deselection: Summing up. Sample \& Hold: Rick Lugg's Blog. Available at: http://sampleandhold-r2.blogspot.com/2011/05/costof-deselection-10-summing-up.html (accessed December 19, 2011).

McKenzie, Elizabeth M., Robert E. Dugan, and Kristin Djorup. 2000. Leaving the Federal Depository Library Program. Journal of Academic Librarianship 26 (4): 282-285.

\title{
APPENDIX A \\ Agencies Assigned to OSUL by Shared Housing Agreement
}

\author{
Department \\ Agriculture (A) \\ Interior (I) \\ National Oceanic and Atmospheric Administration (1970-) (C 55.1-141) \\ National Oceanographic Data Center (1970-) (C 55.290:) \\ National Marine Fisheries Service (1970-) (C 55.300) \\ Oceanic and Atmospheric Research Office (C 55.700:) \\ FAA (1958-1967) (FAA) - inactive \\ MCB: Board of Mediation and Conciliation (1913-1921) (MCB) - inactive \\ National Aeronautics and Space Administration (1958-) (NAS) \\ National Science Foundation (1950-) (NS) \\ Federal Mine Safety and Health Review Commission (1978) (Y 3.M 66:) - inactive \\ Nuclear Regulatory Commission (1975-) - inactive (Y 3.N 88:) \\ Tennessee Valley Authority (1933-)(Y 3.T 25:) - inactive
}




\section{APPENDIX B}

\section{Floor Space in Square Feet Devoted to Government Documents}

Floor Space

in Square Feet

Notes

\begin{tabular}{lrc}
\hline Print documents & 2,592 & Includes aisle space between stacks rows \\
Serial Set & 254 & \\
Maps: Oregon 7.5" topos & 12 & maps s.f. - size of map cases only \\
Maps: U.S. 1:100,000 \& & 27 & $\begin{array}{c}\text { Other federally produced maps are located } \\
\text { throughout the map collection-general, } \\
\text { 1:250,000 topos }\end{array}$ \\
historic, and "storage" maps \\
Maps: U.S. 7.5" topos & 130 & \\
Maps: U.S. historic topos & 24 & \\
Maps: nautical charts & 33 & \\
Valley docs fiche & 46 & LC classified docs fiche interspersed in LC \\
& & fiche; does not include NTIS or ERIC \\
CDs & 18 & fiche; size of fiche cabinets only \\
Posters & NA cabinets only \\
Total square feet & 3,136 & posters are one drawer in a map case \\
\hline
\end{tabular}

\section{APPENDIX C}

Map of Government Documents in the Valley Library

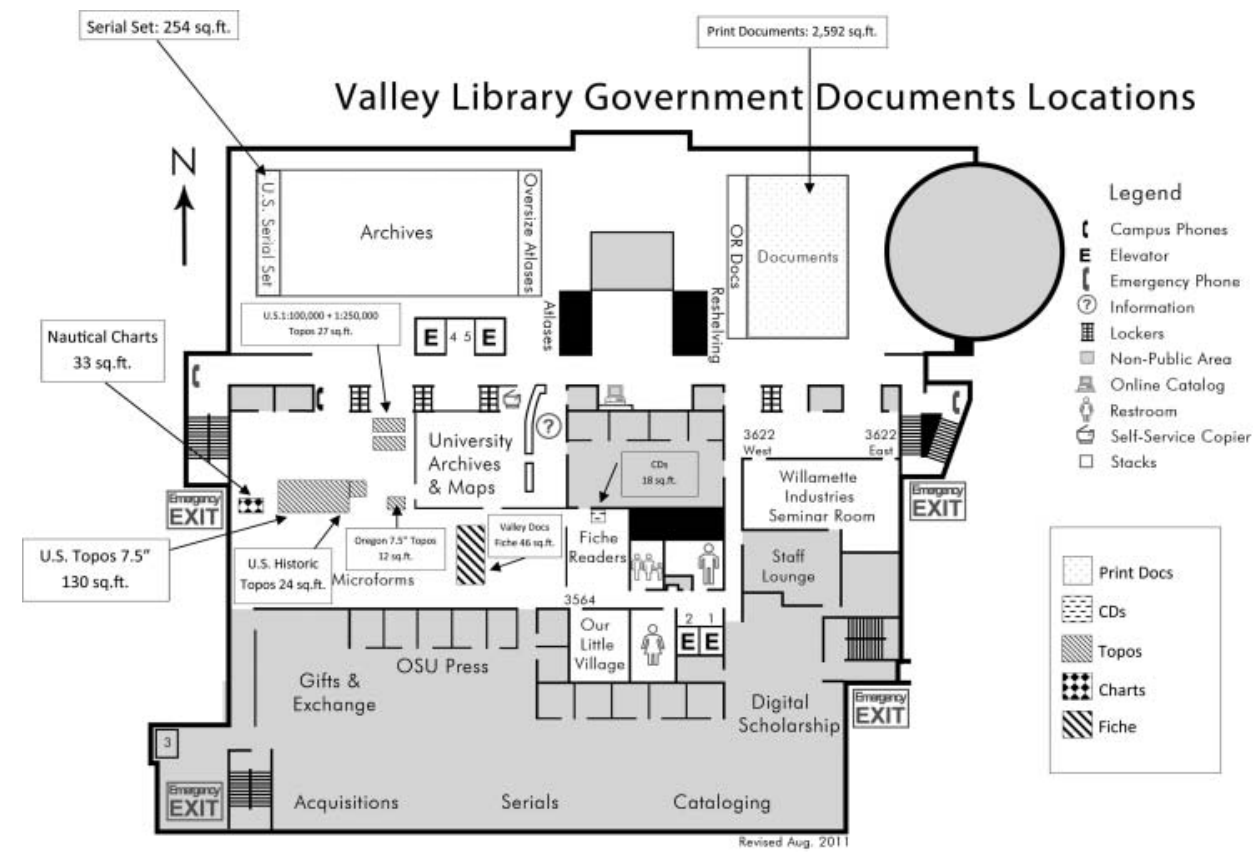

